\title{
Sublethal effects of sediment-associated uranium on Chironomus riparius (Diptera: Chironomidae) larvae
}

\author{
V. Dias ${ }^{1}$, B. Ksas, V. Camilleri and J .M. Bonzom ${ }^{1}$ \\ Laboratory of Radioecology and Ecotoxicology, Institute for Radioprotection and Nuclear \\ Safety, DEI/SECRE/LRE, Cadarache, Bât. 186, BP. 3, 13115 Saint Paul Lez Durance \\ Cedex, France
}

\begin{abstract}
In aquatic ecosystems, sediments constitute a reservoir for many of the most persistent chemicals that are introduced into surface waters. Sediments provide a habitat for various benthic macroinvertebrates, which could be exposed to sediment-associated chemicals both directly and via food intake. These organisms play an important role on the structure and the functioning of aquatic ecosystems. Among the non-biologically essential metals, data concerning uranium (U) fate and effects on freshwater benthic macroinvertebrates are sparse. The present study aimed at estimating effects of a chronic U exposure on Chironomus riparius larvae. To achieve this goal, a 10-d laboratory bioassay was performed exposing, via the sediment, first instar larvae to a gradient of $U$ concentrations $(0,2.97,6.07$, $11.44,23.84 \mu \mathrm{g} \mathrm{U} / \mathrm{g}$ dry wt). Significant negative effects on mortality, development time and growth were detected at $6.07,6.07$ and $2.97 \mu \mathrm{g} \mathrm{U} / \mathrm{g}$ dry wt, respectively. The results underlined a possible impact of $\mathrm{U}$ at the population level at environmentally occurring $U$ concentrations. This study confirmed the need for more research on the role of $U$ on benthic macroinvertebrate.
\end{abstract}

\section{INTRODUCTION}

Uranium (U) is among the metals naturally present and/or released into freshwater ecosystems. As a result of anthropogenic activities (nuclear fuel cycle, agriculture use - phosphate based fertilisers -, research laboratories and military use of depleted uranium) $U$ concentrations in aquatic ecosystems may be increased [2]. Due to the high affinity of heavy metals with sediments, the latter can represent an important storage compartment. This is particularly true for $\mathrm{U}$ [3]. In French rivers, $\mathrm{U}$ concentrations in sediments range between 0.24 and $6.29 \mu \mathrm{g} \mathrm{U} / \mathrm{g}$ dry wt [1]. U concentrations reached values as high as $450 \mu \mathrm{g} \mathrm{U} / \mathrm{g}$ dry wt in sediments nearby an U mine in Spain [4].

Sediments also provide a habitat for various benthic macroinvertebrates, which play an important role on the structure and the functioning of aquatic ecosystems. However, their burrowing activity may lead to elevated exposition to $\mathrm{U}$ concentrations [5]. Little is known about $\mathrm{U}$ fate and effects on freshwater benthic macroinvertebrates. To our knowledge, only one study has evaluated the effects (mortality) of U on Chironomidae in acute exposure [6]. The authors exposed Chironomus tentans to U via the water. Only BEAK Inc. evaluated the toxicity of $\mathrm{U}$ via the sediment on a benthic macroinvertebrate: Hyalella azteca, a test species used in ecotoxicology [7]. After 14 days of exposure, detectable effects on survival of $H$. azteca juveniles were observed for $\mathrm{U}$ concentrations $\geq 6.1 \mu \mathrm{g} \mathrm{U} / \mathrm{g}$ dry wt. No data are available on the impact of $\mathrm{U}$ on Chironomidae via the sediment. As shown by BEAK Inc. [7], mortality of benthic macroinvertebrates is currently the only endpoint used to determine $U$ toxicity

\footnotetext{
${ }^{1}$ Corresponding authors: victor.dias@irsn.fr or jean-marc.bonzom@irsn.fr
} 
via the sediment. However, sublethal effects (e.g. inhibition growth, inhibition reproduction), which are usually used for chronic toxicity tests, as endpoints have never been taken into account in U studies. These endpoints are in most case more sensitive than lethality [8].

Among freshwater macroinvertebrates, Chironomus riparius is commonly utilized in ecotoxicology to assess the toxicity of contaminated sediments [9]. This species is used as a test species because of (i) its ubiquitous occurrence and ecological relevance; (ii) its contact with sediment throughout its larval development [5]; (iii) its easy culture [10].

The purpose of the present investigation was to assess potential sublethal effects of a chronic $\mathrm{U}$ exposure on C. riparius larvae. To achieve this goal, a 10-d laboratory bioassay was performed exposing first instar larvae to a gradient of $\mathrm{U}$ concentrations via the sediment.

\section{MATERIALS AND METHODS}

\subsection{Preparation of a spiked U-sediment}

The artificial sediment was composed of $88 \%$ of silica sand with particles size distribution ranging from 150 to $300 \mu \mathrm{m}$ (VWR-Prolabo, France), and $12 \%$ of alpha-cellulose (Sigma-Aldrich, France). It was spiked with four different levels of $\mathrm{U}$ concentrations. Larvae were exposed to 2.97, 6.07, 11.44, and $23.84 \mu \mathrm{g} \mathrm{U} / \mathrm{g}$ dry wt. A control (no added $\mathrm{U}$ ) was also performed. For each $\mathrm{U}$ concentration, $2 \mathrm{~kg}$ of artificial sediment were mixed with $9 \mathrm{~L}$ of artificial water $\left(\mathrm{pH}=7 ;\left[\mathrm{MgSO}_{4}, 7 \mathrm{H}_{2} \mathrm{O}\right]=24.65 \mathrm{mg} / \mathrm{L} ;\left[\mathrm{Na}_{2} \mathrm{CO}_{3}\right]=2.54 \mathrm{mg} / \mathrm{L}\right.$; $\left[\mathrm{CaCl}_{2}, 2 \mathrm{H}_{2} \mathrm{O}\right]=42.63 \mathrm{mg} / \mathrm{L} ;\left[\mathrm{MgCl}_{2}, 6 \mathrm{H}_{2} \mathrm{O}\right]=19.31 \mathrm{mg} / \mathrm{L} ;[\mathrm{NaCl}]=6.55 \mathrm{mg} / \mathrm{L} ;\left[\mathrm{NaNO}_{3}\right]=28.9 \mathrm{mg} / \mathrm{L} ;$ $\left[\mathrm{KNO}_{3}\right]=16.18 \mathrm{mg} / \mathrm{L}$ ). To reach the desired concentration, the artificial water was spiked with repeated additions of a stock solution of uranyl nitrate $\left(\mathrm{UO}_{2}\left(\mathrm{NO}_{3}\right)_{2}, 6 \mathrm{H}_{2} \mathrm{O} ; 663 \mathrm{mg} \mathrm{U} / \mathrm{L}\right.$; Sigma-Aldrich, France). Sediments were then stored during 1 week to allow $\mathrm{U}$ adsorption on sediment particles. Seven days before the 10-d bioassay, the contaminated-water was removed, and the sediment was placed in test beakers (volume $=400 \mathrm{~mL}$ ) with clean artificial water, aeration, food and maintained in the same condition that during the bioassay to allow bacterial development (see below) [9].

\subsection{Experimental design}

C. riparius larvae in the experiment originated from the laboratory cultures and were grown according to Environment Canada's methods [10]. As shown by several authors, the first instar is considered to be the most sensitive stage to metal toxicity [11,12]. 1-d post-hatch larvae (first instar) were thus used in the present experiment. During the experiment, beakers of the five $U$ conditions (ten replicates) were set randomly in incubator maintained at $21 \pm 1^{\circ} \mathrm{C}$ on a $16: 8$-h light-dark photoperiod. Each beaker was filled with $80 \mathrm{~mL}$ of sediment $(60 \mathrm{~g}$ dry wt) and $310 \mathrm{~mL}$ of artificial water aerated (dissolved oxygen maintained up to $6 \mathrm{mg} / \mathrm{L}$ ).

At day 0 , ten 1-d old larvae were introduced in each beaker. As recommended, all beakers received $6 \mathrm{mg}$ of Tetramin ${ }^{\circledR}$ fish food (Tetrawerke, Melle, Germany) each day except day 1 and day 2 [13]. Temperature, $\mathrm{pH}$, dissolved oxygen, and conductivity were measured daily. At the end of the assay (day 10) surviving larvae were collected and stored in $70 \%$ ethanol prior to analysis $[9,14]$. From each test beakers, at days $0,3,6$ and $10,10 \mathrm{~mL}$ of water samples for the analysis of $\mathrm{U}$ were collected, filtered $\left(0.45 \mu \mathrm{m}\right.$; cellulose acetate; Minisart $\left.{ }^{\circledR}\right)$, immediately acidified $\left(2 \% \mathrm{HNO}_{3}\right)$ and stored at $4{ }^{\circ} \mathrm{C}$ prior to analysis. At day 10, sediment samples for the analysis of $\mathrm{U}$ were collected from each beaker and stored at $4{ }^{\circ} \mathrm{C}$ until mineralisation. Samples were then digested using a combination of $\mathrm{HNO}_{3}$ and $\mathrm{H}_{2} \mathrm{O}_{2}$. Samples were filtered $\left(0.45 \mu \mathrm{m}\right.$; cellulose acetate; Minisart $\left.{ }^{\circledR}\right)$ and diluted to volume with acidified $\left(2 \% \mathrm{HNO}_{3}\right) 18-\mathrm{M} \Omega$ deionised water. The reagents used were sufficient to completely digest alpha-cellulose, and desorb $U$ from silica-sand particle. For all samples the $U$ concentrations were determined by ICP-AES. 
After 10-d of exposure, three endpoints were studied:

Survival. Mean percentage of survival larvae after 10-d of exposure was calculated as follow:

$$
\% \text { survival }=100 * N_{\text {day } 10} / N_{\text {day } 0}
$$

where $N_{\text {day } 0}$ is the number of first instar larvae introduced in the test beaker at day 0 and $N_{\text {day10 }}$ the number of surviving larvae at day $10[8,15,16]$.

Development. The instar of larvae is determined with the head capsule width $[10,13,17]$. In all treatments, mean head capsule width was calculated with the surviving larvae.

Growth. Effects of U on larvae growth were measured following the larva length [13, 18]. In all treatments, mean larva length was calculated for both the surviving the third, and the fourth instar [10]. Larva length and head capsule width were measured using a binocular microscope with a computer-connected camera, and the Biovisiocom 2000® software.

\subsection{Data analysis}

According to assumptions test (Kolmogorov-Smirnov test), differences between treatments for each endpoints were evaluated using either one-way analysis of variance followed by post-hoc pairwise comparison Tukey test, or Kruskall-Wallis test followed by Nemenyi test [19]. All statistical analyses were carried out using SPSS 9.0, and considered significant at a probability $\leq 0.05$.

\section{RESULTS}

\subsection{Physico-chemical measurements}

During all the experiment, the water physico-chemical parameters were constant in all treatments. Mean temperature, $\mathrm{pH}$, dissolved oxygen, conductivity of water during 10-d exposure, and $\mathrm{U}$ concentrations measured in water and sediment samples are reported in table 1.

Table 1. Mean U concentrations $( \pm \mathrm{SE})$ measured in the water and sediment samples. Mean temperature, $\mathrm{pH}$, dissolved oxygen, and conductivity $( \pm \mathrm{SE})$ during 10-d exposure. n.d.: not detectable.

\begin{tabular}{|c|c|c|l|c|c|}
\hline $\begin{array}{l}\text { U sediment } \\
(\mu \mathrm{g} U / \mathrm{g} \text { dry wt. })\end{array}$ & U water $(\mu \mathrm{g} / \mathrm{L} \mathrm{U})$ & Temperature $\left({ }^{\circ} \mathrm{C}\right)$ & $\mathrm{pH}$ & $\begin{array}{l}\text { Dissolved oxygen } \\
(\mathrm{mg} / \mathrm{L})\end{array}$ & $\begin{array}{l}\text { Conductivity } \\
(\mu \mathrm{S} / \mathrm{cm})\end{array}$ \\
\hline n.d. & n.d. & $20.9(0.1)$ & $7.17(0.02)$ & $7.3(0.1)$ & $272(4)$ \\
\hline $2.97(0.04)$ & $10.22(1.28)$ & $20.9(0.1)$ & $7.23(0.01)$ & $7.4(0.1)$ & $274(2)$ \\
\hline $6.07(0.02)$ & $28.39(0.67)$ & $20.9(0.1)$ & $7.18(0.02)$ & $7.5(0.1)$ & $268(2)$ \\
\hline $11.44(0.08)$ & $51.28(1.55)$ & $20.9(0.1)$ & $7.12(0.02)$ & $7.5(0.1)$ & $276(3)$ \\
\hline $23.84(0.21)$ & $85.17(1.80)$ & $20.9(0.1)$ & $7.01(0.01)$ & $7.4(0.1)$ & $269(2)$ \\
\hline
\end{tabular}

\subsection{Biological measurements}

After 10-d exposure, survival of $C$. riparius significantly decreased (ANOVA: $F_{4,44}=21.500 ; p<0.001$ ). According to the Tuckey test, the 0 and $2.97 \mu \mathrm{g} \mathrm{U} / \mathrm{g}$ dry wt treatments exhibited a weaker mortality than the 6.07, 11.44, and $23.84 \mu \mathrm{g} \mathrm{U} / \mathrm{g}$ dry wt treatments (Fig. 1). 


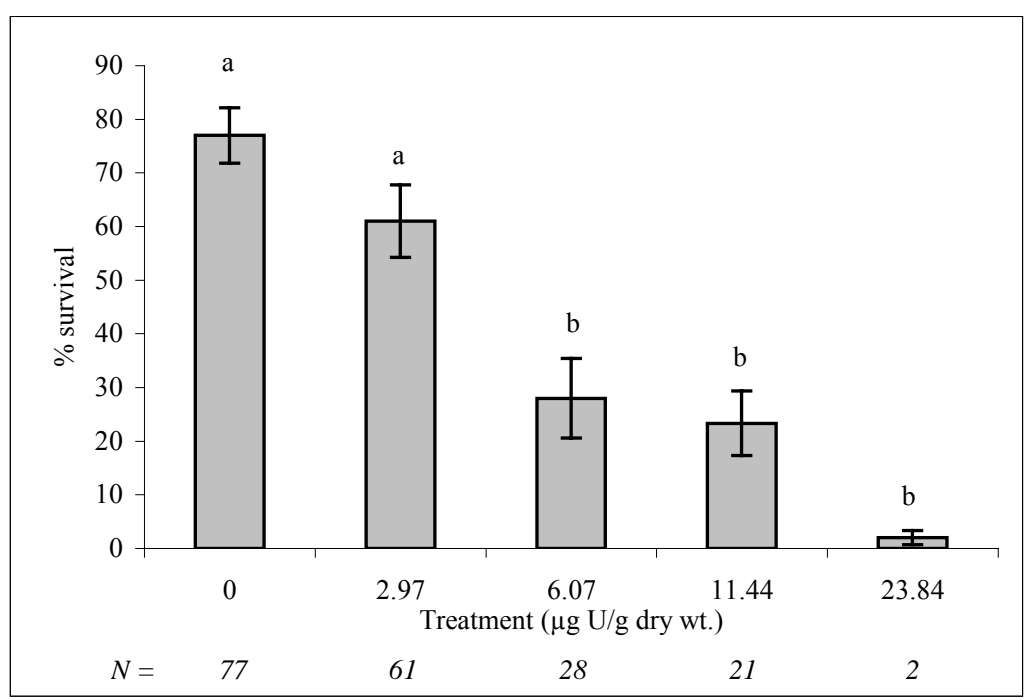

Figure 1. Percentage of survival (mean $\pm \mathrm{SE}$ ) after 10 days of exposure under different $\mathrm{U}$ treatments. Treatments with the same letter are not significantly different $(\mathrm{p} \leq 0.05) . \mathrm{N}=$ sample size at day 10 .

Head capsule width of survival larvae was significantly affected by $U$ concentration (Kruskall-Wallis: chi2 $=20.809 ;$ d.f. $=4 ; p<0.001)$. Nemenyi test showed detectable differences in head capsule width for $\mathrm{U}$ concentrations $\geq 6.07 \mu \mathrm{g} \mathrm{U} / \mathrm{g}$ dry wt (Fig. 2).

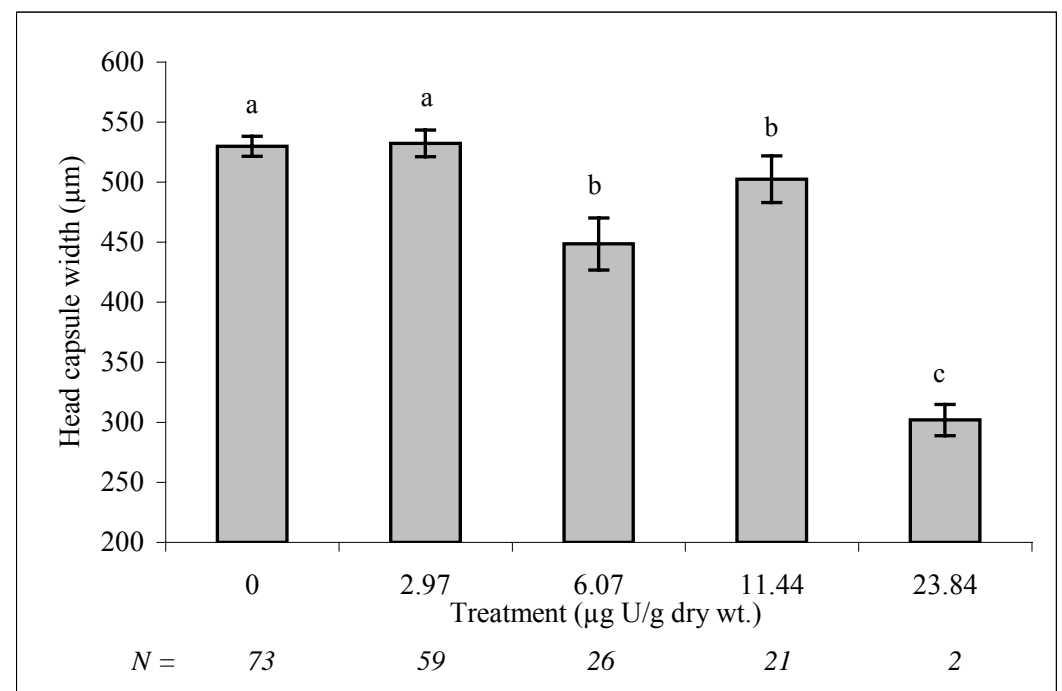

Figure 2. Head capsule width of survival larvae (mean $\pm \mathrm{SE}$ ) after 10 days of exposure under different treatments. Treatments with the same letter are not significantly different $(\mathrm{p} \leq 0.05) . \mathrm{N}=$ sample size at day 10 .

The fourth instar larvae length was significantly decreased with increasing $U$ concentrations (ANOVA: $F_{3,145}=10.366 ; p<0.001$ ). Tuckey test shows detectable differences in fourth instar larva length for $\mathrm{U}$ concentrations $\geq 2.97 \mu \mathrm{g} \mathrm{U} / \mathrm{g}$ dry wt (Fig. 3). 


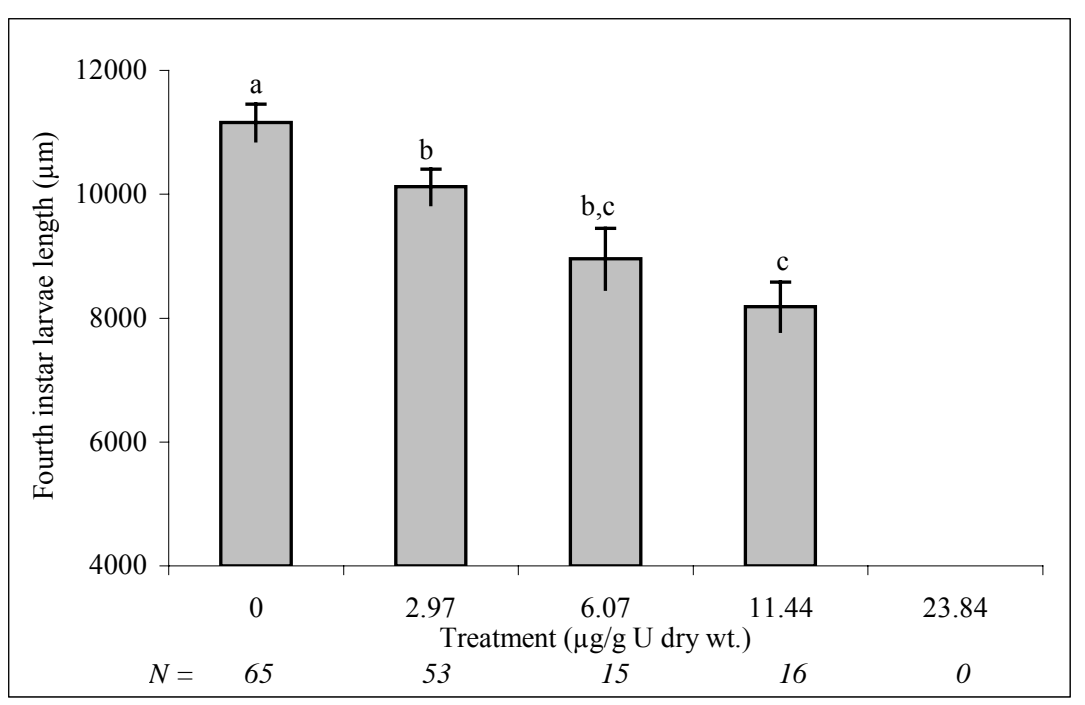

Figure 3. Surviving fourth instar larvae length (mean $\pm \mathrm{SE}$ ) after 10 days of exposure under different treatments. Treatments with the same letter are not significantly different $(\mathrm{p} \leq 0.05) . \mathrm{N}=$ sample size at day 10 .

Concerning the third instar larvae length (data not shown), no significant difference was observed between treatments (Kruskall-Wallis: $\operatorname{chi} 2=4.293$; d.f. $=4 ; \mathrm{p}=0.368$ ).

\section{DISCUSSION}

This investigation aimed at assessing potential sublethal effects of a chronic $\mathrm{U}$ exposure on C. riparius larvae. Experimental conditions in the present work $(\mathrm{T}, \mathrm{pH}$, dissolved oxygen; see table 1) led to a $77 \%$ of survival larvae in the control treatment $(0 \mu \mathrm{g} \mathrm{U} / \mathrm{g}$ dry wt; see Fig. 1$)$. As previously shown a percentage of survival $>70 \%$ corresponds to optimal conditions for C. riparius [17]. Thus the observed variations in survival, development, and growth endpoints, observed in treatments can be mainly attributed to U. Moreover two U contamination pathways, the sediment and the water column, may both explained observed effects. Indeed chemical analysis of water samples showed that sediment desorbed U (see table 1).

$\mathrm{U}$ concentrations used in this work were environmentally relevant. Indeed, in French rivers, U concentrations in sediments range between 0.24 and $6.29 \mu \mathrm{g} \mathrm{U} / \mathrm{g}$ dry wt [1]. Moreover, higher level can be present in some specific sites. For example, in the south Platte river basin (USA) Heiny and Tate [20] sampled twenty three sites. They observed U concentrations ranging from 5.50 to $25 \mu \mathrm{g} \mathrm{U} / \mathrm{g}$ dry wt. Lozano et al. [4] measured nearby a mine in Spain U concentrations as high as $450 \mu \mathrm{g} \mathrm{U} / \mathrm{g}$ dry wt. Survival results showed significant negative effect at $6.07 \mu \mathrm{g} \mathrm{U} / \mathrm{g}$ dry wt $(28.0( \pm 7.4) \%$ of survival; see Fig. 1). To our knowledge, only one study has examined the effects of a sediment-associated $U$ on benthic macroinvertebrates [7]. The test species was Hyalella azteca, another species usually used in sediment toxicity tests $[7,21]$. After 14-d of exposure to natural sediments spiked with uranyl nitrate, the authors exhibited significant decreases in the percentage of surviving juveniles for $\mathrm{U}$ concentrations $\geq 6.1 \mu \mathrm{g} \mathrm{U} / \mathrm{g}$ dry wt. The results of the present work are in good agreement with the work on H. azteca.

Nevertheless, mortality may not be the best endpoint for sediment toxicity assessment. In their work, Sibley et al. [8] said that use of mortality as an endpoint is not accurate for sediment risk assessment. Therefore, sublethal endpoints are needed for a better sediment toxicity assessment because of a better sensitivity and ecological relevance. Accordingly, sublethal effects on 
development and growth were measured. The mean head capsules width decreased with increasing $\mathrm{U}$ concentrations (Fig. 2). This result is obviously related to an increase in the relative abundances of third instar larvae collected after 10-d (data not shown). A large number of pollutants have already been shown to affect larva development time. Among them, lead, mercury, and $\beta$-sitosterol increase larva development time of $C$. riparius [14]. This is the first time that $U$ may be found to induce a development delay in C. riparius. This is of particular interest since this delay in development could have broader consequences on C. riparius reproduction. Indeed, Postma et al. [18] who previously showed that cadmium increased larvae development time of $C$. riparius also observed a decrease in the population growth rate.

In addition to head capsule width, larvae length was also investigated. Results of larvae length for both third and fourth instar showed that effects of $U$ were only detectable for the last instar larvae (Fig. 3). Indeed, growth inhibition of the fourth instar, was detectable at $\mathrm{U}$ concentrations as low as $2.97 \mu \mathrm{g} \mathrm{U} / \mathrm{g}$ dry wt (Fig. 3). During the first three instars of C. tentans, development of somatic tissue dominates. Gametic tissue development is initiated during the fourth instar [22]. Larvae must reach a critical somatic tissue mass before energy is allocated to the development of reproductive tissue [15]. Exposed to sediment-associated U, C. riparius larvae may need more time to reach the critical somatic tissue mass. This may explain the delay in development observed after a 10-day exposure.

Numerous studies have demonstrated that reduced growth in aquatic invertebrates, independent of its cause, may be associated with reductions in reproductive output [15, 23-26]. Among them, Sibley et al.[15] studied the effect of food supply on growth and reproduction of the midge $C$. tentans. They provided direct association between larval growth history and reproductive output of adults. Accordingly, Sibley et al. proposed growth to be used to predict changes that occur at the population level. Their conclusions were confirmed by Pery [13] through a modelling approach. Due to effects of $\mathrm{U}$ on both the development time and the growth, effects on reproduction of C. riparius can be expected. This is particularly interesting since the observed growth inhibition was the most sensitive endpoints of the present study revealing potential $\mathrm{U}$ effects at the population level.

\section{CONCLUSION}

The experimental design developed allowed to assess the toxicity of sediment associated $\mathrm{U}$ at both lethal and sublethal levels using three endpoints (mortality, development, and growth) of C. riparius larvae. It has to be noticed that detectable effects on mortality, development time and growth were measured at environmentally occurring U concentrations. Until now, however, mortality was the only endpoint used to assess sediment-associated $U$ toxicity on benthic macroinvertebrates. The present laboratory results confirmed that using mortality as an endpoint of $C$. riparius is not accurate for sediment risk assessment [8]. However, inhibition of growth seems to be a more sensitive endpoint than mortality in the estimation of $U$ impact on macroinvertebrates because of a more subtle sensitivity, and a strong ecological relevance. Indeed, according to these results, impact of $U$ can be expected on reproduction of C. riparius. This underlined the need for more research to be undertaken at the population level to estimate effects of sediment associated $U$ on life cycle of $C$. riparius.

\section{Acknowledgments}

The authors would like to thank Sylvain Dujols for technical assistance, Dr. Frank Denison for advice in conducting the preparation of a spiked-sediment, and Dr. Christophe Vasseur for helpful comments on earlier versions of the manuscript. This research was funded by the IRSN EnvirHom Programme. 


\section{References}

[1] Lambrechts A., Foulquier L., and Garnier-Laplace J., Radiat. Prot. Dosim. 45 (1992) 253-256.

[2] Colle C., Garnier-Laplace J., Roussel-Debet S., Adam C., and Baudin J.P., "Comportement de l'uranium dans l'environnement dans l'environnement", l'uranium de l'environnement à l'homme (EDP sciences, 2001) pp. 187-211.

[3] Ribera D., Labrot F., Tisnerat G., and Narbonne J.F., Rev. Environ. Contam. T. 146 (1996) 53-89.

[4] Lozano J.C., Blanco Rodriguez P., and Vera Tome F., J. Environ. Radioactiv. 63 (2002) 153-171.

[5] Thomas P. and Liber K., Environ. Int. 27 (2001) 341-353.

[6] Poston T.M., Hanf R.W., and Simmons M.A., Water Air and Soil Poll. 22 (1984) 289-298.

[7] BEAK International Incorporated, Toxicity of uranium and trace metals discharged to the aquatic environment (Atomic Energy Control Board, Ottawa, Ontario, project No.: 12020.1, 1998) pp. 45.

[8] Sibley P.K., Ankley G.T., and Benoit D.A., Environ. Toxicol. Chem. 20 (2001) 1296-1303.

[9] Martinez E.A., Moore B.C., Schaumloffel J., and Dasgupta N., Environ. Toxicol. Chem. 20 (2001) 2475-2481.

[10] Environnement Canada, Méthode d'essai biologique: essai de survie et de croissance des larves dulcicoles de chironomes (Chironomus tentans ou Chironomus riparius) dans les sédiments. (Environnement Canada, Ottawa, Ontario, SPE 1/RM/32, 1997) pp. 133.

[11] Nebeker A.V., Cairns M.A., and C.M. W., Environ. Toxicol. Contam. 3 (1984) 151-158.

[12] Naylor C. and Howcroft J., Chemosphere. 35 (1997) 1831-1845.

[13] Pery A.R.R., Modélisation des effets toxiques sur le chironome Chironomus riparius de l'individu à la population ( $\mathrm{PhD}$ thesis, Université Claude Bernard, Lyon, France, 2003) pp. 119.

[14] Vermeulen A.C., Liberloo G., Dumont P., Ollevier F., and Goddeeris B., Chemosphere. 41 (2000) 1581-1591.

[15] Sibley P.K., Benoit D.A., and Ankley G.T., Environ. Toxicol. Chem. 16 (1997) 336-345.

[16] Benoit D.A., Sibley P.K., Juenemann J.L., and Ankley G.T., Environ. Toxicol. Chem. 16 (1997) 1165-1176.

[17] Bonnet C., Développement de bioessais sur sédiments et applications à l'étude, en laboratoire, de la toxicité de sédiments dulçaquicoles contaminés ( $\mathrm{PhD}$ thesis, Université de Metz, Metz, France, 2000) pp. 309.

[18] Postma J.F. and Davids C., Ecotox. Environ. Safe. 30 (1995) 195-202.

[19] Zar J.H., Biostatistical analysis 4th edition (Prentice Hall International, Upper Saddle River, New jersey, USA, 1999) pp. 412.

[20] Heiny J.S. and Tate C.M., Arch. Environ. Contam. Toxicol. 32 (1997) 246-259.

[21] Kuhne W.W., Caldwell C.A., Gould W.R., Fresquez P.R., and Finger S., Environ. Toxicol. Chem. 21 (2002) 2198-2203.

[22] Ineichen H., Reise-Willi U., and Fisher J., Oecologia. 39 (1979) 161-183.

[23] Tolba M.R. and Holdich D.M., Aquat. Toxicol. 1 (1981) 101-112.

[24] Nisbet R.M., Gurney W.S.C., Murdoch W.W., and Mc Cauley M., Biol. J. Linn. Soc. 37 (1989) 79-99.

[25] Moore D.W. and Dillon T.M., J. Exp. Mar. Biol. Ecol. 173 (1993) 231-246.

[26] Ball S.L. and Baker R.L., Freshwater Biol. 34 (1995) 1-12. 